\title{
Temporal distribution of visceral leishmaniasis in Paraíba state, northeastern brazil,
}

\section{by geographic region, 2012-2017}

\author{
Distribuição temporal da leishmaniose visceral na Paraíba, estadlo do nordeste brasileiro, segundo \\ regiões geográficas, 2012-2017 \\ Distribución temporal de leishmaniosis visceral en Paraíba, estado noreste de brasil, según regiones
} geográficas, 2012-2017

\author{
Allan Batista Silva \\ ORCID: https://orcid.org/0000-0001-8202-7212 \\ Federal University of Paraíba, Brazil \\ E-mail: allandobu@gmail.com \\ Hemílio Fernandes Campos Coêlho \\ ORCID: https://orcid.org/0000-0002-7140-3590 \\ Federal University of Paraíba, Brazil \\ E-mail: hemilio@gmail.com \\ Francisca Inês de Sousa Freitas \\ ORCID: https://orcid.org/0000-0002-9027-9652 \\ Federal University of Paraíba, Paraíba, Brazil \\ E-mail: clelia.mota@hotmail.com \\ Sérgio Vital da Silva Júnior \\ ORCID: https://orcid.org/0000-0003-3359-6640 \\ Federal University of Paraíba, Brazil \\ E-mail: sergioenfe1@gmail.com \\ Caliandra Maria Bezerra Luna Lima \\ ORCID: https://orcid.org/0000-0002-3569-9638 \\ Federal University of Paraíba, Brazil \\ E-mail: calilunalima@gmail.com
}

\begin{abstract}
This study aims to analyze the temporal distribution of human (HVL) and canine visceral leishmaniasis (CVL) in the state of Paraíba between 2012 and 2017, by Intermediate and Immediate Geographic Region (GR). As an ecological study with a quantitative approach, data were collected in the LACEN PB database; Dra. Telma Lobo Central Public Health Laboratory, Paraíba; and refer to positive cases of HVL and CVL presented in the state in the period under study. Poisson Regression Modeling was used to quantify the average number of cases from one year to another. The results revealed that the immediate GRs of Mamanguape - Rio Tinto, Campina Grande, and Cajazeiras present a statistically significant increasing trend in the average number of HVL cases. The immediate GRs of Campina Grande, Patos, Cuité - Nova Floresta, Itaporanga, and João Pessoa revealed a significant increase in the average number of CVL cases during the period analyzed. The need for reorganization of disease control operations and preventive actions was confirmed, especially in those regions identified with growth.
\end{abstract}

Keywords: Leishmaniasis; Visceral leishmaniasis; Ecological studies.

\section{Resumo}

Este estudo tem como objetivo analisar a distribuição temporal da leishmaniose visceral humana (LVH) e canina (LVC) no estado da Paraíba entre 2012 e 2017, segundo as Regiões Geográficas (RG) Intermediárias e Imediatas. Trata-se de um estudo ecológico com abordagem quantitativa. Os dados foram coletados na base de dados do LACEN PB - Laboratório Central de Saúde Pública Dra. Telma Lobo, Paraíba e são referentes aos casos positivos de LVH e LVC apresentados no estado, entre o período em estudo. Utilizou o Modelo de Regressão de Poisson para quantificar o número médio de casos de um ano para outro. Os resultados revelaram que as RG Imediatas de Mamanguape - Rio Tinto, Campina Grande e Cajazeiras apresentaram uma tendência crescente, estatisticamente significativa, quanto ao número médio de casos de LVH. Já as RG Imediatas de Campina Grande, Patos, Cuité - Nova Floresta, Itaporanga e João Pessoa apresentaram um aumento crescente significativo no número médio de casos da LVC entre o período analisado no presente estudo. Desse modo, verifica-se a necessidade de reorganização operacional das ações de controle e prevenção da doença, principalmente nas regiões identificadas com crescimento.

Palavras-chave: Leishmaniose; Leishmaniose Visceral; Estudos Ecológicos. 


\begin{abstract}
Resumen
El presente estudio tiene como objetivo analizar la distribución temporal de las leishmaniasis visceral humana (HVI) y canina (VVI) en el estado de Paraíba entre 2012 y 2017, según las Regiones Geográficas Intermedias e Inmediatas (RG). Este es un estudio ecológico con un enfoque cuantitativo. Los datos fueron recolectados en la base de datos de LACEN PB - Laboratorio Central de Salud Pública Dra. Telma Lobo, Paraíba y se refieren a los casos positivos de HVI y LVC presentados en el estado, entre el período de estudio. Usó el modelo de regresión de Poisson para cuantificar el número promedio de casos de un año a otro. Los resultados revelaron que el GR Inmediato de Mamanguape - Rio Tinto, Campina Grande y Cajazeiras mostró una tendencia creciente, estadísticamente significativa, con respecto al número promedio de casos de HVI. El GR Inmediato de Campina Grande, Patos, Cuité Nova Floresta, Itaporanga y João Pessoa, por su parte, mostró un aumento significativo creciente en el número promedio de casos de CVL entre el período analizado en el presente estudio. Por lo tanto, existe la necesidad de una reorganización operativa de las acciones de prevención y control de enfermedades, especialmente en las regiones identificadas con crecimiento.
\end{abstract}

Palabras clave: Leishmaniasis; Visceral leishmaniasis; Estudios ecológicos.

\title{
1. Introduction
}

Visceral leishmaniasis (VL), also known as kala-azar, is a zoonosis of great importance for public health. Considered endemic in 65 countries, VL has an estimated incidence of 400,000 new cases and 50,000 deaths per year (Abrantes, Werneck, Almeida, \& Figueiredo, 2018).

VL is a parasitosis caused by protozoa of the genus Leishmania, and the species Leishmania chagasi is the main cause of the disease in Brazil (Hirschmann, brod, Radin, \& Recuero, 2015; Sales, Chaves, martins, \& Silva, 2017). Its biological cycle is heteroxenic and involves complex interactions between the parasite, the sand-fly vector Lutzomia longipalpis, and the human and canid vertebrate hosts (Barbosa, 2011; Afonso, 2013; Ministério da Saúde, 2014; Figueiredo, Werneck, Cruz, Silva, \& Almeida, 2017).

Due to its close relationship with humans (Miranda, 2008; Anversa, Montanholi, 2016; Castro; 2016), the domestic $\operatorname{dog}$ (Canis familiaris) is the main reservoir of kala-azar in urban areas. It is noteworthy that occurrence of VL in dogs largely precedes human cases, and infections are also recorded in larger numbers (Werneck, 2016). In dogs, VL presents a variable incubation period, and may manifest from 3 to 7 months after the infection, but the animal may spend several years asymptomatically (Ministério da Saúde, 2014; Castro 2016). According to Belo (2012), asymptomatic animals play a role in the transmission chain equivalent to that of symptomatic animals.

In 2006, the Ministry of Health published the Visceral Leishmaniasis Surveillance and Control Program (VLSCP), with the purpose of controlling territorial progress and reducing morbidity and mortality of the disease throughout the national territory (Ministério da Saúde, 2014; Cavalcante \& Vale, 2014). The control actions suggested by this program are mainly aimed at conducting canine seroepidemiological surveys, and reducing lethality through actions involving improvements in procedures for early diagnosis and drug treatment availability. However, studies have demonstrated that despite all of the efforts and resources committed, reduction of VL transmission has not been achieved in the expected quantities (Werneck, 2016; Zuben \& Donalisio, 2016; Toledo et al, 2017).

According to the Ministry of Health, through the Department of Informatics of the Unified Health System, in 2007 the Northeast Region presented 1,726 cases reported in the SINAN - Disease Reporting Information System. In 2014 this value increased by $40.32 \%$, with 2,422 notified cases registered. The increase was also observed in Paraíba, where between 2007 and 2014, notifications in the state increased from 25 to 59 cases (Ministério da Saúde, 2019).

Considering its variable incubation period and severe characteristics, VL should be diagnosed as early as possible, as it may progress to death if not treated (Oliveira \& Pimenta. 2014; Ortiz \& Anversa, 2015; Zuben \& Donalisio, 2016). Studies such as this are of great relevance in identifying state disease regions that require prioritization of control and surveillance measures. 
This study aims to analyze the temporal distribution of human (HVL) and canine (CVL) - visceral leishmaniasis in the state of Paraíba between 2012 and 2017, by Immediate and Intermediate Geographic Regions.

\section{Methodology}

\section{Type of study and research area}

This study is ecological with a quantitative approach (Gil, 2017). Data were collected, between September 2017 and August 2018, to the database of LACEN PB-Central Laboratory of Public Health - Dra. Telma Lobo, Paraíba. The laboratory is considered a reference in the state of Paraíba, applying medium and high complexity testing. The laboratory was also chosen because it maintains data concerning the current scenario of the disease within the state, thus avoiding potential errors and inaccurate conclusions which can occur in ecological studies because of underreporting.

The data refer to positive cases of HVL and CVL recorded in Paraíba during the study period. According to the 2010 Census, conducted by the Brazilian Institute of Geography and Statistics (IBGE), the state of Paraíba has a population of 3,766,528 inhabitants, and is located in the Northeast Region of Brazil (IBGE, 2017a).

The state of Paraiba had been divided into 4 mesoregions and 23 microregions. However, in view of the need to update regional reporting and include the significant increase in internal differentiation, a consequence of the economic, demographic, political and environmental transformations suffered in recent decades, the IBGE in 2017 stipulated a new regional division of the existing Meso- and Micro-regions, to the current delineation of Immediate and Intermediate Geographic Regions. Hence, the state of Paraíba is currently divided into 15 Immediate Geographic Regions and 4 Intermediate Geographic Regions (IBGE, 2017b).

\section{Data sources and sample selection}

The LACEN PB database maintains information collected by municipality in Paraíba on the number of positive cases of HVL and CVL between 2012 and 2017. These data have been divided by region into Immediate and Intermediate Geographic Regions. For suspected cases of HVL, LACEN PB performs Immunochromatography and Indirect Immunofluorescence Reaction (RIFI); for suspected cases of CVL, the laboratory performs Enzyme Immunosorbent Assay (ELISA), Immunochromatography and Indirect Immunofluorescence Reaction. The IBGE (2018) data was also consulted, where the number of inhabitants per municipality was collected, according to official population estimates for the years 2012 to 2017.

\section{Statistical analysis}

Data were tabulated in Microsoft Office Excel, version 10 and submitted to R software. To quantify the average number of cases of HVL and CVL from year to year in the Immediate Geographic Regions, the Poisson Regression Model for Generalized Linear Models was used. The number of positive cases of HVL and CVL (dependent variables) were modeled according to year (independent variable).

In addition, a logarithm of the human and canine populations was used in the model by means of the term "offset", as an important component for model adjustment. The equation used is as follows:

$$
\log \left(\mu_{i}\right)=\log \left(\text { pop }_{\mathrm{i}}\right)+\alpha+\beta * \text { year }
$$

Where, $\mu_{i}=$ number of cases of HVL or CVL per year; $i=1,2,3, \ldots, 6$, representing the years 2012 to 2017; pop $p_{\mathrm{i}}=$ estimated human or canine population per year; $\alpha=$ value of the estimated model constant; $\beta=$ coefficient of the estimated model; year = $1,2,3, \ldots, 6$, representing the years 2012 to 2017 . 
The estimated model served to calculate the average annual percentage variation, using the formula: $\left(\exp ^{\beta}-1\right) * 100 \%$. Trends were classified as increasing, decreasing, or stationary in accordance with the sign of the average annual percentage variation. Trends with $\mathrm{p}<0.05$ were considered significant.

\section{Ethical aspects}

This paper is part of a project entitled "Distribution of cases of visceral leishmaniasis and possible factors that influence its occurrence in the state of Paraíba, Brazil”; approved by the Ethics and Research Committee of the Health Sciences and Health Center at Paraíba Federal University; under CAAE - Certificate for Ethical Appreciation No. 79843717.9.0000.5188, and was carried out within the norms and guidelines in force in Resolution No. 466/12 of the National Health Council. Since the study used secondary data, it was not necessary to produce Free and Informed Consent documentation.

\section{Results}

In the state of Paraíba, between 2012 and 2017, 1,535 suspected cases of HVL were investigated of which 327 (21.3\%) humans were parasitized; 65 (4.24\%) presented inconclusive results, 71 (4.63\%) were undetermined, 1,066 (69.45\%) were not parasitized and $6(0.38 \%)$ were not tested for unknown reasons. For CVL, in the same time period, 13,846 suspected cases of CVL were investigated; where 6,352 (45.87\%) dogs were parasitized, $32(0,23 \%)$ presented inconclusive results, 886 $(6.40 \%)$ remained undetermined, 6,477 $(46.78 \%)$ were not parasitized, and $99(0.72 \%)$ were not tested for unknown reasons. Of the 223 municipalities in Paraíba, HVL was present in 64 and CVL was present in 99 municipalities.

For HVL, it was observed that the Sousa-Cajazeiras Intermediate Geographic Region presented the highest percentage of positive cases of the disease, being present in $32 \%$ of the 25 municipalities of the region. After this region, the Intermediate Geographic Regions of Patos, Campina Grande and João Pessoa recorded respective percentages of 31.7\%, 27.8\%, and 23.8\% for positive cases of the disease in relation to the total by municipality.

For CVL, it was observed that the Patos Intermediate Geographic Region presented the highest percentage of municipalities with positive cases, with the zoonosis prevalent in $55.6 \%$ of the 63 municipalities in the region. The Intermediate Geographic Regions of João Pessoa, Sousa-Cajazeiras and Campina Grande presented a percentage of municipalities with respective positive cases of $50.8 \%, 40 \%$, and $30.5 \%$. Table 1 presents the percentage of municipalities with positive cases for HVL and CVL divided by Intermediate and Immediate Geographic Regions. 
Table 1: Distribution of Paraiban municipalities with positive cases for HVL and CVL, according to Intermediate and Immediate Geographic Regions, Paraíba, 2012-2017

\begin{tabular}{|c|c|c|c|c|c|c|c|}
\hline \multirow{2}{*}{$\begin{array}{l}\text { Intermediate } \\
\text { Geographic } \\
\text { Region }\end{array}$} & \multirow{2}{*}{$\begin{array}{l}\text { Immediate } \\
\text { Geographic Region }\end{array}$} & \multirow{2}{*}{$\begin{array}{l}\text { Number } \\
\text { Inhabitants } \\
\left(\text { Mean* }{ }^{*} \text { SD } * *\right)\end{array}$} & \multirow{2}{*}{$\begin{array}{l}\text { Total } \\
\text { Mun. }\end{array}$} & \multicolumn{2}{|c|}{ Mun. W/positive cases } & \multicolumn{2}{|c|}{$\begin{array}{l}\text { Number of } \\
\text { positive cases }\end{array}$} \\
\hline & & & & HVL & CVL & $\begin{array}{l}\text { HV } \\
\mathbf{L}\end{array}$ & CVL \\
\hline \multirow{5}{*}{ João Pessoa } & João Pessoa & $1.339 .566( \pm 54.491)$ & 22 & $8(36.4 \%)$ & $13(59.1 \%)$ & 80 & 3242 \\
\hline & Guarabira & $318.098( \pm 3.088)$ & 26 & $2(7.7 \%)$ & $9(34.6 \%)$ & 4 & 36 \\
\hline & Mamanguape - Rio & $142.979( \pm 2.992)$ & 10 & $4(40 \%)$ & $5(50 \%)$ & 12 & 127 \\
\hline & Tinto & & & & & & \\
\hline & Itabaiana & $66.187( \pm 389)$ & 5 & $2(40 \%)$ & $5(100 \%)$ & 2 & 42 \\
\hline \multirow{4}{*}{$\begin{array}{l}\text { Campina } \\
\text { Grande }\end{array}$} & Campina Grande & $951.193( \pm 15.908)$ & 47 & $15(31.9 \%)$ & $15(31.9 \%)$ & 72 & 418 \\
\hline & Cuité - Nova Floresta & $93.471( \pm 1.484)$ & 10 & $1(10 \%)$ & $4(40 \%)$ & 3 & 46 \\
\hline & Monteiro & $55.580( \pm 1.043)$ & 7 & $1(14.3 \%)$ & $2(28.6 \%)$ & 2 & 4 \\
\hline & Sumé & $51.859( \pm 658)$ & 8 & $3(37.5 \%)$ & $1(12.5 \%)$ & 6 & 2 \\
\hline \multirow{5}{*}{ Patos } & Patos & $263.841( \pm 4.122)$ & 26 & $9(34.6 \%)$ & $18(69.2 \%)$ & 25 & 235 \\
\hline & Itaporanga & $123.281( \pm 842)$ & 15 & $6(40 \%)$ & $4(26.7 \%)$ & 21 & 44 \\
\hline & $\begin{array}{l}\text { Catolé do Rocha - São } \\
\text { Bento }\end{array}$ & $116.439( \pm 2.123)$ & 10 & $3(30 \%)$ & $9(90 \%)$ & 70 & 655 \\
\hline & Pombal & $66.757( \pm 685)$ & 7 & $1(14.3 \%)$ & $1(14.3 \%)$ & 2 & 1 \\
\hline & Princesa Isabel & $62.160( \pm 837)$ & 5 & $1(20 \%)$ & $3(75 \%)$ & 1 & 15 \\
\hline \multirow{2}{*}{$\begin{array}{l}\text { Sousa- } \\
\text { Cajazeiras }\end{array}$} & Sousa & $140.915( \pm 1.980)$ & 13 & $6(46.2 \%)$ & $4(30.8 \%)$ & 19 & 1011 \\
\hline & Cajazeiras & $152.782( \pm 2.467)$ & 12 & $2(16.7 \%)$ & $6(50 \%)$ & 8 & 474 \\
\hline
\end{tabular}

Mun = Municipalities; * Average number of inhabitants per Immediate Geographic Region from 2012 to 2017; ** SD = Standard Deviation; Source: Research Data (2018).

The Immediate Geographic Regions presenting the highest number of HVL cases were João Pessoa, Campina Grande, Catolé do Rocha-Sao Bento, Patos, and Itaporanga (TABLE 1). The immediate geographic regions of João Pessoa, Sousa, Catolé do Rocha-Sao Bento, Cajazeiras and Campina Grande presented the highest number of CVL cases (Table 1).

At the municipal level, it was also observed that between 2012 and 2017, both HVL and CVL presented territorial expansions throughout the state of Paraíba, since both had begun newly in cities that had previously presented no cases. Examples include the municipalities of Gurjão, San Francisco, Sao Jose do Sabugi, Coremas, Santana de Mangueira, and Umbuzeiro, which until 2013 had no reported cases of HVL; and also the municipalities of Rio Tinto, Santa Rita, Pombal, Pedra Lavrada, Cubati, and Alcantil, which until 2015 had reported no cases of HVL.

At a $95 \%$ confidence level we verified a statistically significant increasing trend in the average number of cases of HVL in the Immediate Geographic Regions of Mamanguape - Rio Tinto, Campina Grande, and Cajazeiras; with a one-year growth patterns of 124\%, 19\%, and 103\%, respectively (Table 2). As can be seen in Table 2, the immediate geographic regions of João Pessoa and Catolé do Rocha - Rio Tinto presented significant decreases in the average number of human cases of VL. 
Table 2: Average annual percentage change in HVL according to Immediate Geographic Region, Paraíba, 2012-2017.

\begin{tabular}{|c|c|c|c|c|}
\hline \multirow{2}{*}{$\begin{array}{l}\text { Immediate Geographic } \\
\text { Region }\end{array}$} & \multicolumn{4}{|c|}{ Human Visceral Leishmaniasis } \\
\hline & $\boldsymbol{\beta}$ & $\exp ^{\beta}[C I 95 \%]$ & $\%^{\beta}$ & Trend \\
\hline João Pessoa & $-0.37 * * *$ & $0.69[0.6 ; 0.8]$ & -31 & Decreasing \\
\hline Guarabira & -1.62 & $0.2[0.01 ; 2.42]$ & & Stationary \\
\hline Mamanguape - Rio Tinto & $0.8 * *$ & $2.24[1.41 ; 4.17]$ & 124 & Increasing \\
\hline Itabaiana & $-{ }^{a}$ & - & - & - \\
\hline Campina Grande & $0.18 *$ & $1.19[1.04 ; 1.38]$ & 19 & Increasing \\
\hline Cuité - Nova Floresta & 0.17 & $1.18[0.6 ; 2.57]$ & & Stationary \\
\hline Monteiro & 0.17 & $1.18[0.51 ; 3.19]$ & & Stationary \\
\hline Sumé & 0.53 & $1.69[1 ; 3.43]$ & & Stationary \\
\hline Patos & 0.03 & $1.03[0.82 ; 1.3]$ & & Stationary \\
\hline Itaporanga & 0.21 & $1.23[0.95 ; 1.62]$ & & Stationary \\
\hline Catolé do Rocha - São & $-0.33 * * *$ & $0.72[0.62 ; 0.83]$ & -28 & Decreasing \\
\hline Bento & & & & \\
\hline Pombal & 0.63 & $1.87[0.75 ; 9.11]$ & & Stationary \\
\hline Princesa Isabel & $-b$ & - & - & - \\
\hline Sousa & -0.03 & $0.97[0.74 ; 1.26]$ & & Stationary \\
\hline Cajazeiras & $0.71 *$ & $2.03[1.21 ; 4.15]$ & 103 & Increasing \\
\hline
\end{tabular}

${ }^{\mathrm{a}}$ region where the disease was present only in 2017 ; ${ }^{b}$ region where the disease was present only in $2012 * \mathrm{p}<0.05 ; * * \mathrm{p}<0.01 ; * * * \mathrm{p}<0.001$; $\beta=$ Beta Coefficient; $\exp =$ exponential; $\mathrm{CI}=$ Confidence Interval; $\%{ }^{\beta}=$ Average annual percentage change, $\left(\exp ^{\beta}-1\right) * 100 \% \times$ Source: Research Data (2018).

Table 3 shows that at the 95\% confidence level, the Immediate Geographic Regions of Campina Grande, Patos, Cuité - Nova Floresta, Itaporanga, and João Pessoa presented significant increases in the average number of CVL cases in the period analyzed; and between 2012 and 2017, the Guarabira, Catolé do Rocha - São Bento, and Mamanguape - Rio Tinto Intermediate Geographic Regions presented significant decreases in the average number of CVL cases (Table 3). 
Table 3: Average annual percentage change in CVL according to Immediate Geographic Region, Paraíba, 2012-2017.

\begin{tabular}{|c|c|c|c|c|}
\hline \multirow{2}{*}{$\begin{array}{l}\text { Immediate Geographic } \\
\text { Region }\end{array}$} & \multicolumn{4}{|c|}{ Canine Visceral Leishmaniasis } \\
\hline & $\boldsymbol{\beta}$ & $\exp ^{\beta}[\mathrm{CI} 95 \%]$ & $\%^{\beta}$ & Trend \\
\hline João Pessoa & $0.09 * * *$ & $1.09[1.07 ; 1.11]$ & 9 & Increasing \\
\hline Guarabira & $-2.32 * * *$ & $0.1[0.03 ; 0.77]$ & -90 & Decreasing \\
\hline Mamanguape - Rio Tinto & $-0.36 * * *$ & $0.7[0.62 ; 0.78]$ & -30 & Decreasing \\
\hline Itabaiana & 0.12 & $1.13[0.95 ; 1.36]$ & & Stationary \\
\hline Campina Grande & $0.34 * * *$ & $1.4[1.32 ; 1.49]$ & 40 & Increasing \\
\hline Cuité - Nova Floresta & $0.27 * *$ & $1.32[1.1 ; 1.59]$ & 32 & Increasing \\
\hline Monteiro & 0.08 & $1.08[0.6 ; 2.02]$ & & Stationary \\
\hline Sumé & $-{ }^{a}$ & - & - & - \\
\hline Patos & $-0.29 * * *$ & $1.33[1.23 ; 1.45]$ & 33 & Increasing \\
\hline Itaporanga & $0.26 * *$ & $1.29[1.08 ; 1.56]$ & 29 & Increasing \\
\hline Catolé do Rocha - São & $-0.38 * * *$ & $0.68[0.65 ; 0.72]$ & -32 & Decreasing \\
\hline \multicolumn{5}{|l|}{ Bento } \\
\hline Pombal & -0.18 & $0.84[0.17 ; 2.95]$ & & Stationary \\
\hline Princesa Isabel & 0.1 & $1.1[0.82 ; 1.5]$ & & Stationary \\
\hline Sousa & $-0.2 * * *$ & $0.82[0.79 ; 0.85]$ & -18 & Decreasing \\
\hline Cajazeiras & $-0.18 * * *$ & $0.84[0.79 ; 0.89]$ & -16 & Decreasing \\
\hline
\end{tabular}

${ }^{a}$ region where the disease was present only in 2017; ** $\mathrm{p}<0.01 ; * * * \mathrm{p}<0.001 ; \beta=$ Beta Coefficient; $\exp =\operatorname{exponential;} \mathrm{CI}=\mathrm{Confidence}$ Interval; $\%^{\beta}=$ Average annual percentage change, $\left(\exp ^{\beta}-1\right) * 100 \%$. Source: Research Data $(2018)$.

\section{Discussion}

WHO considers VL as one of the priority tropical diseases in the world, and if not treated properly, the individual can progress to death (Abrantes et al, 2018; Baborsa, 2011). According to the Brazilian Ministry of Health, in Brazil there are on average over 3,000 new cases of human kala-azar per year (Ministério da Saúde, 2018). What is more worrying is that according to data from SINAN, the disease has been showing territorial expansion and an increase in the number of cases in most Brazilian states (Reis, Baleiro, Fonseca, \& Gonçalves, 2017). According to Alves et al.24, 13,638 new cases of the disease were registered between 2011 and 2014 in 1,460 Brazilian municipalities; with 70\% of the cases occurring in only 204 municipalities, which include 10 capitals and 56 cities with $\cong 100,000$ inhabitants.

In the present study, it was observed that in the state of Paraíba both HVL and CVL present expansions. According to some scholars, one of the factors for the process of expansion and transition of VL is the migration of the population from rural to urban areas (Barbosa, 2011; Teles, 2011; Lisboa et al, 2016). In the state of Paraíba it was observed that between the 2000 and 2010 censuses, the total population increased 3,443,825 to 3,766,528 inhabitants. The percentage of rural population decreased from $28.94 \%$ to $24.63 \%$, while the percentage of urban population increased from $71.06 \%$ to $75.37 \%$ (IBGE, 2017a). The migration process leads to profound changes in both landscapes and ecosystems, such as deforestation from housing construction. In addition, adaptation to the new artificial environments occurs in certain species populations, such as the sand-fly (Cardim, Guirado, Dibo, \& Chiaravalloti, 2016; Freitas, Sampaio Filho, Santos, Lima, \& Nunes-Pinheiro, 2013). As a result, human and other living beings are more exposed to the etiological agents of diseases such as VL - Leishmania chagasi. 
Barros et al (2013) and Rocha, Silva, Oliveira, Silveira e Wanderley (2015) report that poverty is a factor related to VL in municipalities, especially in large urban centers. This was evident in the present study where, according to the 2010 census, the municipalities identified with VL cases of the Intermediate Geographic Regions of Campina Grande and Patos had the lowest per capita incomes. These regions presented the largest number of municipalities with positive cases for VL in the state.

Other studies show that VL affects mainly people in less favored socioeconomic conditions (Ortiz \& Anversa, 2015; Barros et al, 2013; Belo et al, 2013; Barbosa, Guimarães, \& Luz, 2016). In the present work, the municipalities of Santana de Mangueira (Immediate Geographic Region of Itaporanga), Umbuzeiro, Cubati, Alcantil (Immediate Geographic Region of Campina Grande) and Pedra Lavrada (Immediate Geographic Region of Cuité-Nova Floresta) indeed recorded cases of VL over the analyzed period. According to the latest census these municipalities present more than $65 \%$ of their populations as vulnerable to poverty, with the municipality of Santana de Mangueira presenting the highest percentage in the state, and registering $80.61 \%$ of the population as vulnerable to poverty (Atlas Brasil, 2013). We conclude that most of the inhabitants of these municipalities have a per capita household income of 255.00 Brazilian Reals (BRL) or less per month, and likely live in precarious conditions which may have influenced the onset of the disease.

In this work it was verified that HVL presents a growing trend in the Immediate Geographic Regions of Mamanguape - Rio Tinto, Cajazeiras, and Campina Grande, being the first two greater, since they present a growth average of more than $100 \%$ for the number of human disease cases from one year to another within the period studied.

In relation to CVL we verified a growing trend over the years in certain regions of Paraíba state, such as the Immediate Geographic regions of João Pessoa, Campina Grande, Cuité - Nova Floresta, Patos, and Itaporanga. This is of great concern since in addition to canines being the most important domestic reservoir for kala-azar, they play a significant role in maintaining the disease cycle.

The importance of domestic dogs reflects not only a higher prevalence of the disease than in humans, but also a greater number of asymptomatic animals. According to estimates, about $80 \%$ of the dog population is infected (Marcondes \& Rossi, 2013). Laurenti et al (2013), when evaluating the ability of dogs infected with Leishmania (L.) infantum chagasi to transmit the parasite to the vector, observed that asymptomatic dogs maintain highly infectious and are capable of infecting sandflies. Still, Fernandes et al (2016) found in their study that free-living dogs that live in the Paraiban cities of João Pessoa, Campina Grande, Patos, Sousa, and Cajazeiras are four times more likely to develop VL than domestic animals. For reasons like this, dogs are one of the main targets of disease control programs in the country, with actions aimed at these animals, seeking to reduce this prevalence.

However, controlling VL is still considered to be complex (Barbosa et al, 2016). Besides performing early diagnoses and treatment, approaches towards reservoir control and reduction of vector populations vary. One of the goals of the Visceral Leishmaniasis Surveillance and Control Program (PVCLV) is to reduce the risk of transmission by controlling both the reservoir population, and the disease vector. However, such control is a great challenge, and in view of the expansion presented by kala-azar, the current measures are considered by scholars as inefficient (Werneck, 2016; Zuben \& Donalisio, 2016; Toledo et al, 2017; cardim et al, 2016).

According to Werneck et al (2008), a fundamental reason for the lack of effectiveness of these measures is the lack of a permanent surveillance system, which would involve extensive use of both human and financial resources. According to the author cited, other factors relating to infected dogs may also contribute to failures in controlling domestic reservoirs. Some of these factors are: inadequate sensitivity of the diagnostic tests commonly used to detect infectious dogs; delays between diagnosis and treatment, and the high canine rates of both infection and infectivity. We believe these are some of the reasons that have led to the increase in the number of cases of the disease in the regions presented in this study. 


\section{Final Considerations}

Considering the present study's results, VL is expanding in Paraíba and has been presenting significant growth in the number of cases over the years. The Immediate Geographic Regions of Mamanguape - Rio Tinto, Cajazeiras, Joao Pessoa, Cuité - New Forest, Patos, Itaporanga and Campina Grande presented significant growth in the average number of positive VL cases. These regions are therefore at risk of and contribute to the expansion and growth of the disease in the state. Thus, operational reorganization of disease control and prevention actions, especially in the regions identified with growth is needed. It is also noteworthy that the municipalities in the Campina Grande Immediate Geographic Region need even greater attention, since the region presents a growing trend for the number of positive cases of both human and canine kala-azar. In addition, in order to contribute to the scientific understanding of the disease, it is important to develop research identifying factors related to the occurrence of VL in the state, and to define prevention and control strategies more effectively.

\section{References}

Abrantes, T. R., Werneck, G. L., Almeida, A. S., \& Figueiredo, F. B. (2018). Fatores ambientais associados à ocorrência de leishmaniose visceral canina em uma área de recente introdução da doença no estado do Rio de Janeiro, Brasil. Cad Saúde Pública 34(1):e00021117.

Afonso, M. M. S. (2013). Estudos sobre Lutzomyia (lutzomyia) longipalpis: hábito alimentares, infecção natural por Leishmania (Leishmania) infantum chagasi e correlação com a expansão da leishmaniose visceral americana. Tese de doutorado, Escola Nacional de Saúde Pública Sergio Arouca.

Anversa, L., Montanholi, R. J. D., \& Sabino, D. L. (2016). Avaliação do conhecimento da população sobre leishmaniose visceral. Rev Inst Adolfo Lutz, 75:1685-93.

Alves, E. B., Costa, C. H. N., Carvalho, F. A. A., Cruz, M. S. P., \& Werneck, G. L. (2016). Risk profiles for Leishmania infantum infection in Brazil. Am J Trop Med Hyg, 94(6):1276-81.

Atlas Brasil. (2013). Atlas do Desenvolvimento Humano no Brasil. http://www.atlasbrasil.org.br/2013/pt/home/

Barbosa, M. N., Guimarães, E. A. A., \& Luz, Z. M. P. (2016). Avaliação de estratégia de organização de serviços de saúde para prevenção e controle da leishmaniose visceral. Epidemiol Serv Saude, 25(3):563-74.

Barbosa, D. S. (2011). Distribuição espacial e definição de áreas prioritárias para vigilância da leishmaniose visceral no município de São Luís, Ma ranhãa, Brasil. Dissertaçãode Mestrado, Escola Nacional de Saúde Pública Sérgio Arouca.

Barros, L. M., Moreira, R. A. N., Araújo, T. M., Frota, N. M., Caetano, J. A., \& Feitosa, A. C. L. (2013). Aspectos clínicos e epidemiológicos da leishmaniose visceral em crianças. J Res Fundam Care Online, 6(3):966-75.

Belo, V. S. (2012). Fatores associados à leishmaniose visceral nas Américas. Dissertação de mestrado, Escola Nacional de Saúde Pública Sergio Arouca, Rio de Janeiro, RJ, Brasil.

Belo, V. S., Werneck, G. L., Barbosa, D. S., Simões, T. C., Nascimento, B. W. L., Silva, E. S., \& Struchiner, C. J. (2013). Fators associated with visceral leishmaniasis in the Americas: a systematic review and meta-analysis. PLoS Negl Trop Dis, 7(4):e2182.

Castro, C. O. (2016) Análise da distribuição geográfica dos casos de leishmaniose visceral canina no município do Rio de Janeiro de 2011 a 2014. Dissertação de mestrado, Escola Nacional de Saúde Pública Sérgio Arouca.

Cardim, M. F. M., Guirado, M. M., Dibo, M. R., \& Chiaravalloti Neto, F. (2016). Leishmaniose visceral no estado de São Paulo, Brasil: análise espacial e espaço-temporal. Rev Saúde Pública, 50(48):1:11.

Cavalcante, I. J. M., \& Vale, M. R. (2014). Aspectos epidemiológicos da leishmaniose visceral (kala-azar) no Ceará no período de 2007 a 2011. Rev Bras Epidemiol, 17(4):911-24.

Fernandes, A. R. F., Pimenta, C. L. R. M., Vidal, I. F., Sartori, R. S., Araújo, R. B., Melo, M. A., Langoni, H., \& Azevedo, S. S. (2016). Risk factors associated with seropositivity for leishmania spp. And Trypanosoma cruzi in dogs in the state of Paraiba, Brazil. Rev Bras Parasitol Vet, $25(1): 90-8$.

Figueiredo, A. B. F., Werneck, G. L., Cruz, M. S. P., Silva, J. P., \& Almeida, A. S. (2017). Uso e cobertura do solo e prevalência de leishmaniose visceral canina em Teresina, Piauí, Brasil: uma abordagem utilizando sensoriamento remoto orbital. Cad Saúde Pública, 33(10):e00093516.

Freitas, J. C. C., Sampaio Filho, A. P., Santos, G. J. L., Lima, A. L., \& Nunes-Pinheiro, D. C. S. (2013). Analysis of seasonality, tendencies and correlations in human and canine visceral leishmaniasis. Acta Sci Vet, 41(1151):1-8.

Gil, A. C. (2017). Como elaborar projetos de pesquisa (6a ed). Atlas.

Gomes, A. M., Alexandre, M. K. M., Gonzaga, D. S. S., Holanda, H. Á., Noronha, R. B., Gonçalves, D. E., \& Ferreira, R. J. Vigilância sorológica da leishmaniose humana e canina no município de Farias Brito, Estado do Ceará, Brasil. (2017). Biota Amazônia, 7(1):63-8. 
Hirschmann, L. C., Brod, C. S., Radin, J., Simon, C. F., \& Recuero, A. L. C. (2015). Leishmaniose visceral canina; comparação de métodos sorológicos em cães de área indene do Rio Grande do Sul no Brasil. Rev Patol Trop, 44(1):33-44.

Instituto Brasileiro de Geografia e Estatística. Paraíba. (2017a). Paraíba. https://cidades.ibge.gov.br/brasil/pb/panorama

Instituto Brasileiro de Geografia e Estatística. (2017b). Divisão regional do Brasil em regiões geográficas imediatas e regiões geográficas intermediárias. IBGE.

Instituto Brasileiro de Geografia e Estatística. Estimativas da população. (2018). Estimativa de população. hftp://ftp.ibge.gov.br/Estimativas_de_Populacao/

Laurenti, M. D., Rossi, C. N., Matta, V. L., Tomakane, T. Y., Corbett, C. E., Secundino, N. F., Pimenta, P. F. P., \& Marcondes, M. (2013). Asymptomatic dogs are highly competent to transmit Leishmania (Leishmania) infantum chagasi to the natural vector. Vet Parasitol, 196(3-4):296-300.

Lisboa, A. R., Leite, F. C., Dantas, A. E. F., Oliveira, I. B., Evangelista, T. R., \& Sousa, J. B. G. (2016). Análise epidemiológica de leishmaniose visceral em municípios do sertão paraibano. REBES, 6(3):05-12.

Marcondes, M., \& Rossi, C. N. (2013). Leishmaniose visceral no Brasil. Braz J Vet Res Anim Sci, 50(5):341-52.

Ministério da Saúde. (2014). Manual de vigilância e controle da leishmaniose visceral. Brasília: Ministério da Saúde.

Ministério da Saúde. (2019). Sistema de Informação de Agravos de Notificação. http://www2.datasus.gov.br/DATASUS/index.php?are $\mathrm{a}=0203 \& \mathrm{id}=29892192 \& \mathrm{VObj}=\mathrm{http}: / /$ tabnet.datasus.gov.br/cgi/deftohtm.exe?sinannet/cnv/leishv.

Ministério da Saúde. (2018). Sistema de Informação de Agravos de Notificação. http://www2.datasus.gov.br/DATASUS/index.php? area $=0203 \& \mathrm{id}=29892192 \& \mathrm{VObj}=\mathrm{http}: / /$ tabnet.datasus.gov.br/cgi/deftohtm.exe?sinannet/cnv/leishv.

Miranda, G. M. D. (2008). Leishmaniose visceral em Pernambuco: a influência da urbanização e da desigualdade social. Dissertação de mestrado, Fundação Oswaldo Cruz, Recife, PE, Brasil.

Oliveira, E. M., \& Pimenta, A. M. (2014). Perfil epidemiológico das pessoas portadoras de Leishmaniose visceral no município de Paracatu - MG no período de 2007 a 2010. REME, 18(2):371-375.

Ortiz, R. C., \& Anversa, L. (2015). Epidemiologia da Leishmaniose visceral em Bauru, São Paulo, no período de 2004 a 2012 : um estudo descritivo. Epidemiol Serv Saude, 24(1):97-104.

Reis, L. L., Baleiro, A. A. S., Fonseca, F. R., \& Gonçalves, M. J. F. (2017). Changes in the epidemiology of visceral leishmaniasis in Brazil from 2001 to 2014. Rev Soc Bras Med Trop, 50(5):638-45.

Rocha, T. J. M., Silva, K. K. M., Oliveira, V. C., Silveira, L. J. D., Wanderley, F. S., \& Calheiros, C. M. L. (2015). Perfil epidemiológico relacionado aos casos de letalidade por leishmaniose visceral em Alagoas: uma análise entre os anos de 2007 a 2012. Rev Ciênc Farm Apl, 2015;36(1):17-20.

Sales, D. P., Chaves, D. P., Martins, N. S., \& Silva, M. I. S. (2017). Aspectos epidemiológicos da leishmaniose visceral canina e humana no estado do Maranhã, Brasil (2009-2012). Rev Bras Cienc Vet, 24(3):144-50.

Teles, E. J. C. (2011). Perfil epidemiológico da leishmaniose visceral em Barcarena, um município minerário no estado do Pará, Brasil. Dissertação de mestrado, Escola Nacional de Saúde Pública, Fundação Oswaldo Cruz, Belém, PA, Brasil.

Toledo, C. R. S., Almeida, A. S., Chaves, S. A. M., Sobroza, P. C., Toledo, L. M., \& Caldas, J. P. (2017). Vulnerabilidade à transmissão da leishmaniose visceral humana em área urbana brasileira. Rev Saúde Pública, 51(49):1-11.

Werneck, G. L. (2016). Controle da leishmaniose visceral no Brasil: o fim de um ciclo? Cad Saúde Pública, 32(6):eED010616.

Werneck, G. L., Pereira, T. J. C. F., Farias, G. C., Silva, F. O., Chaves, F. C., Gouvêa, M. V., Costa, C. H. N., \& Carvalho, F. A. A. (2008). Avaliação da efetividade das estratégias de controle da leishmaniose visceral na cidade de Teresina, Estado do Piauí, Brasil: resultados do inquérito inicial - 2004. Epidemiol Serv Saude, 17(2):87-96.

Zuben, A. P. B. V., \& Donalisio, M. R. (2016). Dificuldades na execução das diretrizes do Programa de Vigilância e Controle da Leishmaniose Visceral em grandes municípios brasileiros. Cad Saúde Pública, 32(6):e00087415. 